\title{
Combined Treatment With Pembrolizumab and Allogenic BK Virus-Specific T Cells in Progressive Multifocal Leukoencephalopathy
}

\author{
A Case Report
}

Rebecca Wicklein, Simon Heidegger, MD, Mareike Verbeek, MD, Britta Eiz-Vesper, MD, Britta Maecker-Kolhoff, MD, Jan Stefan Kirschke, MD, Agata Page, PhD, Thomas Korn, MD, Bernhard Hemmer, MD, and Marcus Deschauer, MD

Neurol Neuroimmunol Neuroinflamm 2021;8:e1042. doi:10.1212/NXI.0000000000001042

\section{Abstract}

\section{Objective}

We report a combination of $\mathrm{BK}$ virus-specific $\mathrm{T}$ cells and pembrolizumab as a treatment option in progressive multifocal leukoencephalopathy (PML).

\section{Results}

A 57-year-old male patient diagnosed with PML presented a fast-progressing right hemiparesis, aphasia, and cognitive deficits. Brain MRI showed a severe leukoencephalopathy with diffusion restriction. The patient was treated with 10 doses of pembrolizumab ( $2 \mathrm{mg} / \mathrm{kg}$ body weight) in differing intervals and 2 partially human leukocyte antigen-matched allogenic BK virus-specific $\mathrm{T}$ cell transfusions after the fifth pembrolizumab treatment. Although pembrolizumab alone decreased the viral load but failed to control the virus, BK-specific $\mathrm{T}$ cell transfer further enhanced the decline of JC virus copies in the CSF. Moreover, the regression of leukoencephalopathy and disappearance of diffusion restriction in subsequent brain MRI were observed. The combined treatment resulted in a clinical stabilization with improvements of the cognitive and speech deficits.

\section{Discussion}

This case supports the hypothesis that pembrolizumab is more efficient in the presence of an appropriate number of functional antigen-specific $\mathrm{T}$ cells. Thus, the combined treatment of pembrolizumab and virus-specific $\mathrm{T}$ cells should be further evaluated as a treatment option for PML in future clinical trials.
Correspondence

R. Wicklein

rebecca.wicklein@tum.de 


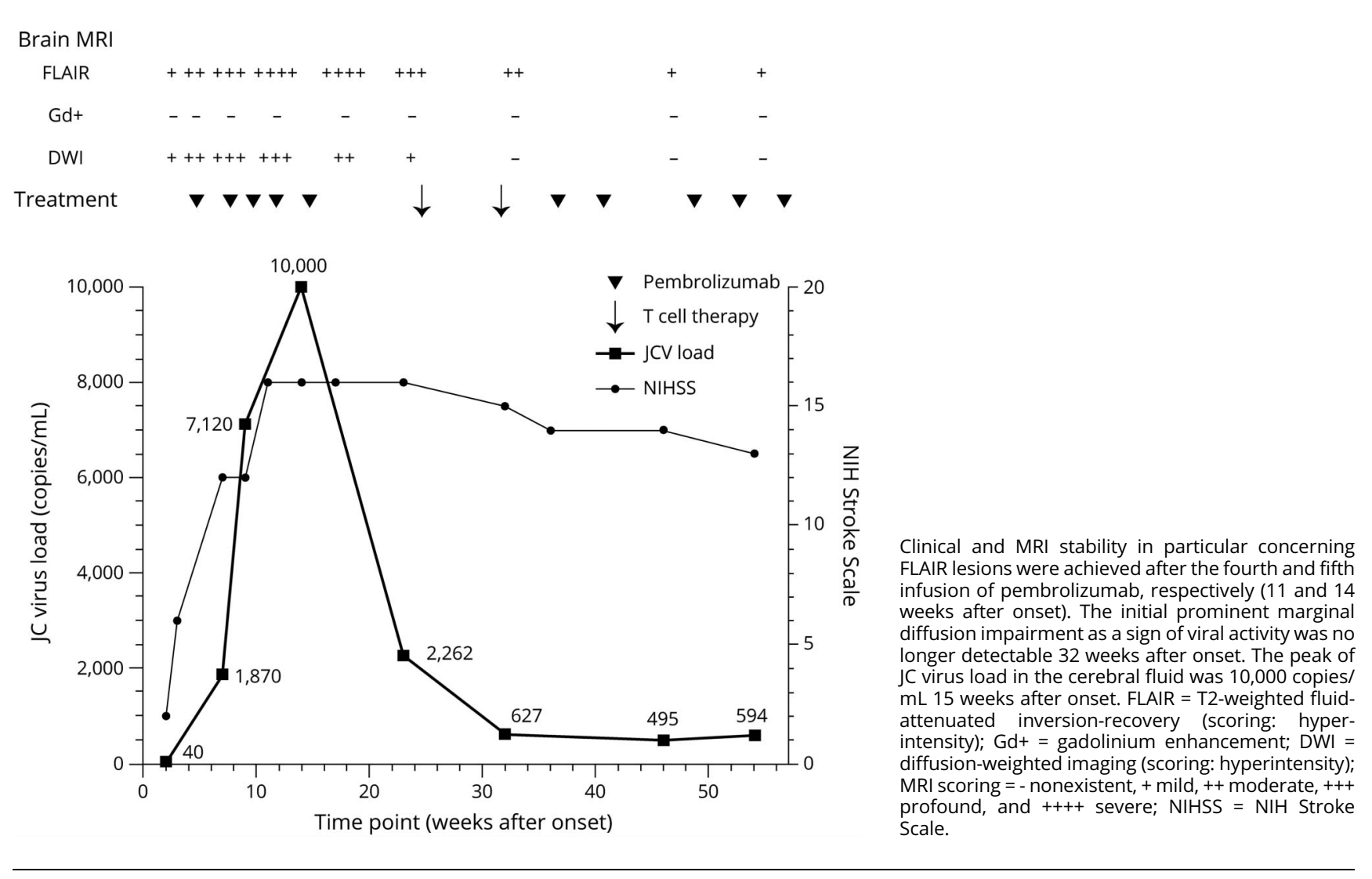

Progressive multifocal leukoencephalopathy (PML) is a rare disease caused by the reactivation of $\mathrm{JC}$ virus in immunocompromised patients, often with poor outcome. There is no standard therapy, but case series showed promising results regarding 2 treatment options: In 2019, treatment with the anti-programmed cell death protein 1 (PD-1) antibody pembrolizumab resulted in clinical stabilization, decrease in virus load, and no further progression in brain MRI in 5 of 8 patients with PML. ${ }^{1} \mathrm{PD}-1$ is an inducible surface receptor and negative regulator of $\mathrm{T}$ cell lytic function. In chronic viral infections, persistent exposure to viral antigens can result in permanent PD-1 expression and $\mathrm{T}$ cell exhaustion. ${ }^{2}$ It was hypothesized that pembrolizumab boosts antiviral activity by blocking the PD-1 pathway in otherwise dysfunctional $\mathrm{T}$ cells, suggesting that pembrolizumab treatment relies on preexisting virus-specific T cells. ${ }^{3}$ In 2018 , a small case series reported a favorable ouotcome in 2 of 3 patients with PML after treatment with allogenic BK virus-specific $\mathrm{T}$ cells from healthy donors. ${ }^{4} \mathrm{BK}$ virus has a high sequence homology with JC virus, and consequently, these T cells expanded with a pool of BK peptides showed cross-reactivity with JC virus-derived peptides. In this case study, according to CARE guidelines, ${ }^{5}$ we report the results of the combined treatment with pembrolizumab and BK virusspecific $\mathrm{T}$ cells in a patient with PML.

\section{Results}

The 57-year-old male patient was in complete remission of stage IV nodal marginal zone lymphoma (nMZL; R-CHOP21 treatment) diagnosed 4 years before PML onset. He presented with a mild right hemiparesis lasting 1 week. A brain MRI revealed multiple, diffusion impaired, hyperintense T2-weighted fluid-attenuated inversion-recovery (FLAIR) lesions, mainly in the left hemisphere. There was no gadolinium enhancement arguing against a cerebral manifestation of the original lymphoma occurring rarely in patients with nMZL. After rapid clinical progression reflected by an increase of leukoencephalopathy in the subsequent brain MRI 4 days later, the diagnosis of PML was confirmed by the detection of JC virus DNA in the CSF ( 40 copies $/ \mathrm{mL}$, high sensitivity PCR; Unilabs A/S, Copenhagen, Denmark). Apart from signs of increased blood-brain barrier permeability, CSF analysis remained normal. CT scans and a bone marrow biopsy showed no signs of recurrent or novel B cell lymphoma.

Four weeks after onset, we initiated treatment with pembrolizumab ( $2 \mathrm{mg} / \mathrm{kg}$ body weight) with a dosage interval of 4 to 6 weeks. ${ }^{1}$ Three weeks after the initial dose (week 7), the patient was readmitted to hospital because of progressive hemiparalysis with a plegic right arm, cognitive deficits, and 
nonfluent aphasia. We intensified treatment with pembrolizumab by reducing the interval to 2 weeks, in accordance with another pembrolizumab protocol of a PML case. ${ }^{6}$ After 5 treatment courses (week 14), the patient achieved a stable clinical condition, but JC viral load in CSF increased to 10,000 copies $/ \mathrm{mL}$ and further progression of leukoencephalopathy was evident by MRI. At week 23, cranial MRI showed no further progression, but brain atrophy was observed in affected areas. Viral load in CSF was still high $(2,262$ copies $/ \mathrm{mL})$. To enhance virus elimination, we initiated a $5 / 10$ partially human leukocyte antigen (HLA)-matched allogenic BK virus-specific T cell transfusion. ${ }^{4} \mathrm{~T}$ cells from a HLA-matched healthy donor from alloCELL registry $\left(20,000 \mathrm{CD}^{+}\right.$cells $/ \mathrm{kg}$ bodyweight $)$ were administered twice 7 weeks apart (week 24, 31), followed by 5 infusions of pembrolizumab (Figure). Both treatments were tolerated very well. In particular, we did not observe any signs of graft vs host disease. Viral load in CSF dropped to 495 copies/mL (week 46). Brain MRI revealed a slight reduction of FLAIR lesions with a progressive atrophy of affected regions in the left hemisphere and no more diffusion restriction. The patient's clinical condition, particularly aphasia and cognitive deficits, further improved after administration of the virus-specific $\mathrm{T}$ cells. However, the right arm remained plegic.

\section{Discussion}

We report a combination of $\mathrm{BK}$ virus-specific $\mathrm{T}$ cells and pembrolizumab as a treatment option for patients with PML. Although pembrolizumab alone decreased the viral load but failed to control the virus, BK-specific $\mathrm{T}$ cell transfer further enhanced the decline of JC virus copies in the CSF. This case supports the hypothesis that pembrolizumab is more efficient in the presence of an appropriate number of functional antigen-specific $\mathrm{T}$ cells. We did not observe any signs of immune reconstitution inflammatory syndrome. The treatment resulted in clinical improvement and regression of leukoencephalopathy in MRI. Case-control series (and ideally controlled clinical trials) might shed more light on the potential benefit of a sequential or combined treatment with checkpoint inhibitors and allogeneic antigen-specific $\mathrm{T}$ cell transfer in PML.

\section{Study Funding}

The authors report no targeted funding.

\section{Disclosure}

The authors report no disclosures relevant to the manuscript. Go to Neurology.org/NN for full disclosures.

\section{Publication History}

Received by Neurology: Neuroimmunology \& Neuroinflammation May 10, 2021. Accepted in final form June 10, 2021.

\section{Appendix Authors}

\begin{tabular}{lll}
\hline Name & Location & Contribution \\
\hline Rebecca & Department of Neurology, & Drafting/revision of the \\
Wicklein & Klinikum rechts der Isar, & manuscript for content, \\
& Technical University Munich, & including medical writing for \\
Germany & content, major role in the \\
& & $\begin{array}{l}\text { acquisition of data, and analysis } \\
\text { or interpretation of data }\end{array}$
\end{tabular}

\begin{tabular}{lll}
\hline $\begin{array}{l}\text { Simon } \\
\text { Heidegger, } \\
\text { MD }\end{array}$ & $\begin{array}{l}\text { Medical Department III for } \\
\text { Hematology and Oncology, } \\
\text { Klinikum rechts der Isar, } \\
\text { Technical University Munich, } \\
\text { Germany }\end{array}$ & $\begin{array}{l}\text { Drafting/revision of the } \\
\text { manuscript for content, } \\
\text { including medical writing for } \\
\text { content, major role in the } \\
\text { acquisition of data, and analysis } \\
\text { or interpretation of data }\end{array}$ \\
$\begin{array}{lll}\text { Mareike } \\
\text { Verbeek, } \\
\text { MD }\end{array}$ & $\begin{array}{l}\text { Medical Department III for } \\
\text { Kematology and Oncology, }\end{array}$ & $\begin{array}{l}\text { Major role in the acquisition } \\
\text { of data }\end{array}$ \\
& $\begin{array}{l}\text { Kechnical University Munich, } \\
\text { Termany }\end{array}$ &
\end{tabular}

\begin{tabular}{lll}
\hline Britta Eiz- & Institute for Transfusion & Major role in the acquisition \\
Vesper, MD & $\begin{array}{l}\text { Medicine, Hannover Medical } \\
\text { School, Germany }\end{array}$ & $\begin{array}{l}\text { of data } \\
\text { School }\end{array}$
\end{tabular}

\begin{tabular}{lll}
\hline Britta & Department of Pediatric & Major role in the acquisition \\
Maecker- & Hematology and Oncology, of data \\
Kolhoff, MD & $\begin{array}{l}\text { Hannover Medical School, } \\
\text { Germany }\end{array}$
\end{tabular}

\begin{tabular}{lll}
\hline $\begin{array}{l}\text { Jan Stefan } \\
\text { Kirschke, }\end{array}$ & $\begin{array}{l}\text { Department of } \\
\text { Neuroradiology, Klinikum }\end{array}$ & $\begin{array}{l}\text { Major role in the acquisition } \\
\text { of data }\end{array}$ \\
MD & Rechts der Isar, Technical & \\
& University Munich, Germany & \\
\hline
\end{tabular}

\begin{tabular}{|c|c|c|}
\hline $\begin{array}{l}\text { Agata Page, } \\
\text { PhD }\end{array}$ & $\begin{array}{l}\text { Unilabs A/S, Copenhagen, } \\
\text { Denmark }\end{array}$ & $\begin{array}{l}\text { Major role in the acquisition } \\
\text { of data }\end{array}$ \\
\hline $\begin{array}{l}\text { Thomas } \\
\text { Korn, MD }\end{array}$ & $\begin{array}{l}\text { Department of Neurology and } \\
\text { Institute of Experimental } \\
\text { Neuroimmunology, Klinikum } \\
\text { rechts der Isar, Technical } \\
\text { University Munich; Munich } \\
\text { Cluster for Systems Neurology } \\
\text { (SyNergy), Germany }\end{array}$ & $\begin{array}{l}\text { Drafting/revision of the } \\
\text { manuscript for content, } \\
\text { including medical writing for } \\
\text { content }\end{array}$ \\
\hline
\end{tabular}

\begin{tabular}{lll}
\hline $\begin{array}{l}\text { Bernhard } \\
\text { Hemmer, } \\
\text { MD }\end{array}$ & $\begin{array}{l}\text { Department of Neurology, } \\
\text { Klinikum rechts der Isar, } \\
\text { Technical University Munich; } \\
\text { Munich Cluster for Systems } \\
\text { Neurology (SyNergy), Germany }\end{array}$ & $\begin{array}{l}\text { Drafting/revision of the } \\
\text { manuscript for content, } \\
\text { including medical writing for } \\
\text { content }\end{array}$ \\
\hline $\begin{array}{l}\text { Marcus } \\
\text { Deschauer, } \\
\text { MD }\end{array}$ & $\begin{array}{l}\text { Department of Neurology, } \\
\text { Klinikum rechts der Isar, } \\
\text { Technical University Munich, } \\
\text { Germany }\end{array}$ & $\begin{array}{l}\text { Drafting/revision of the } \\
\text { manuscript for content, } \\
\text { including medical writing for } \\
\text { content, and analysis or } \\
\text { interpretation of data }\end{array}$ \\
\hline
\end{tabular}

\section{References}

1. Cortese I, Muranski P, Enose-Akahata Y, et al. Pembrolizumab treatment for pro gressive multifocal leukoencephalopathy. N Engl J Med. 2019;380(17):1597-1605. doi:10.1056/NEJMoa1815039.

2. Jubel JM, Barbati ZR, Burger C, Wirtz DC, Schildberg FA. The role of PD-1 in acute and chronic infection. Front Immunol. 2020;11:487. doi:10.3389/fimmu.2020.00487.

3. Pawlitzki M, Schneider-Hohendorf T, Rolfes L, et al. Ineffective treatment of PML with pembrolizumab: exhausted memory T-cell subsets as a clue? Neurol Neuroimmunol Neuroinflamm. 2019;6(6):e627. doi:10.1212/NXI.0000000000000627.

4. Muftuoglu M, Olson A, Marin D, et al. Allogeneic BK virus-specific T cells for progressive multifocal leukoencephalopathy. N Engl J Med. 2018;379(15):1443-1451. doi:10.1056/ NEJMoa1801540.

5. Gagnier JJ, Kienle G, Altman DG, Moher D, Sox H, Riley D. The CARE guidelines: consensus-based clinical case reporting guideline development. BMJ Case Rep. 2013; 2013:201554. doi:10.1136/bcr-2013-201554.

6. Rauer S, Marks R, Urbach H, et al. Treatment of progressive multifocal leukoencephalopathy with pembrolizumab. $N$ Engl J Med. 2019;380(17):1676-1677. doi:10. 1056/NEJMc1817193. 


\title{
Neurology \\ Neuroimmunology \& Neuroinflammation
}

\author{
Combined Treatment With Pembrolizumab and Allogenic BK Virus-Specific T Cells in \\ Progressive Multifocal Leukoencephalopathy: A Case Report \\ Rebecca Wicklein, Simon Heidegger, Mareike Verbeek, et al. \\ Neurol Neuroimmunol Neuroinflamm 2021;8; \\ DOI 10.1212/NXI.0000000000001042
}

This information is current as of July 20, 2021

$\begin{array}{ll}\begin{array}{l}\text { Updated Information \& } \\ \text { Services }\end{array} & \begin{array}{l}\text { including high resolution figures, can be found at: } \\ \text { http://nn.neurology.org/content/8/5/e1042.full.html }\end{array} \\ \text { References } & \begin{array}{l}\text { This article cites } 6 \text { articles, } 1 \text { of which you can access for free at: } \\ \text { http://nn.neurology.org/content/8/5/e1042.full.html\#\#ref-list-1 }\end{array} \\ \text { This article, along with others on similar topics, appears in the } \\ \text { following collection(s): } \\ \text { MRI } \\ \text { http://nn.neurology.org//cgi/collection/mri } \\ \text { Viral infections } \\ \text { http://nn.neurology.org//cgi/collection/viral_infections } \\ \text { Information about reproducing this article in parts (figures,tables) or in } \\ \text { its entirety can be found online at: } \\ \text { http://nn.neurology.org/misc/about.xhtml\#permissions } \\ \text { Permissions \& Licensing } \\ \text { Information about ordering reprints can be found online: } \\ \text { http://nn.neurology.org/misc/addir.xhtml\#reprintsus }\end{array}$

Neurol Neuroimmunol Neuroinflamm is an official journal of the American Academy of Neurology.

Published since April 2014, it is an open-access, online-only, continuous publication journal. Copyright

Copyright $\odot 2021$ The Author(s). Published by Wolters Kluwer Health, Inc. on behalf of the American

Academy of Neurology.. All rights reserved. Online ISSN: 2332-7812.

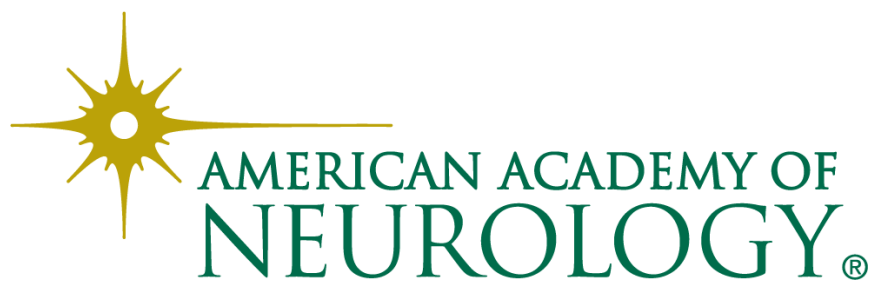

